\title{
THE ROLE OF INTERNATIONALIZATION ORIENTATION IN MEDIATING THE RELATIONSHIP BETWEEN CAPABILITIES AND INTENTION TO EXPORT: AN EMPIRICAL ANALYSIS ON SMES
}

\author{
Yogi Yusuf Wibisono1,", Hotna Marina Sitorus ${ }^{1}$ \\ ${ }^{1}$ Faculty of Industrial Engineering, Parahyangan Catholic University, 40141 Bandung, Indonesia.
}

\begin{abstract}
Small and Medium Enterprises (SMEs) have a strategic role in Indonesia's economy; however, their contribution to the national export is still low. A study on SMEs internationalization becomes important to understand factors that influence SMEs to go international. Using a resource-based view perspective, the objective of this study is to investigate how the organizational capabilities influence the intention of SMEs to export through internationalization orientation. A model was developed that explained the impact of personnel management, product development, and production capabilities on internationalization orientation, and subsequently on the export intention. Primary data were collected through a field survey by distributing structured questionnaires to SMEs in over three months, resulting 86 eligible responses. These empirical data were analyzed to validate proposed model using partial least square - structural equation modeling (PLS-SEM) technique. The results indicated that internationalization orientation mediated partially the effect of personnel management and product development capabilities on SMEs intention to export. The other finding displayed an unexpected result where the influence of production capabilities on internationalization orientation and export intention was found to be insignificant. This study suggests that to increase the intention of SEMs to export, firms must have capabilities in managing their personnel and developing unique and innovative products consistently.
\end{abstract}

\section{INTRODUCTION}

Small and medium enterprises (SMEs) together with micro businesses have a strategic role in national economic development of Indonesia. SMEs have a great contribution to the absorbing a nation's workforce as well as distributing the results of country development. In 2018 the number of SMEs in Indonesia reached 64.19 million units or 99,99\% of all enterprises and contributed to $61.07 \%$ of the national gross domestic product (GDP) which came from all economic sectors including agriculture, stockbreeding, forestry and fishery; mining; manufacturing; electricity, gas, and clean water; construction; commerce, hotel, and restaurant; logistic and communication; finance, leasing, and services (KemenKopUKM, 2018). Although SMEs dominate the total number of businesses and have a larger contribution to the national GDP than the contribution of large enterprises, their contribution to the total export volume was only $14.37 \%$ (KemenKopUKM, 2018). According to Francioni et al. (2016) SMEs tended to have a smaller contribution than what large enterprises contributed to the internationalization process such as exporting the product to foreign markets. With their huge number, SMEs have great potential to give a higher contribution to the export volume. Therefore, a study on SMEs internationalization is important to understand thoroughly their strengths and weaknesses, as well as their threats and opportunities.

The importance of boosting SMEs to go international have attracted numerous researchers to study the internationalization of SMEs. Some studies focused on ex-ante proxy which encompassed the decision to export (BelsoMartinez, 2006; Cassiman et al., 2010; Cerrato \& Piva, 2012), and the internationalization behavior (Omri \& Becuwe, 2014; Serra et al., 2012). Other studies investigated SMEs internationalization from the ex-post proxy perspectives which embraced the export intensity (Belso-Martinez, 2006; Cerrato \& Piva, 2012; Chen et al., 2014; Onkelinx et al., 2015), geographical scope (Cerrato \& Piva, 2012), and the entropy index of internationalization diversification (Cerrato \& Piva, 2012). Considering the majority of Indonesian SMEs have not involved in internationalization that is exporting their products, this study will focus on ex-ante proxy particularly on the intention of SMEs to export their products to foreign markets.

Several factors that encompass internal or external factors were found to have significant impact on the internationalization of SMEs. Most studies which investigated the role of internal factors in encouraging SMEs to go international involved human resources factors, research \& development (R\&D), and organizational related factors. From the perspective of human resources, the study of Onkelinx et al. (2015), Cerrato and Piva (2012), Omri and Becuwe (2014) showed the importance of competency of SMEs personnel in internationalization. Other studies of Omri and Becuwe (2014) and Serra et al. (2012) involved cognitive and socio-demographic aspects as the determinants of SMEs 
internationalization. The study that investigated the R\&D factors highlighted the influence of product development (Serra et al., 2012), technology differentiation (Belso-Martinez, 2006; Serra et al., 2012), and innovation (Cassiman et al., 2010) on SMEs internationalization. Some studies involved organizational factors such as management (Cerrato \& Piva, 2012; Serra et al., 2012) and company ownership (Cerrato \& Piva, 2012; Chen et al., 2014) as determinants of SMEs internationalization. The influence of external factors on SMEs internationalization was investigated by Deng and Zhang (2018); Manolopoulos et al. (2018) that focused on domestic institution quality; and Kuivalainen et al. (2018) that studied the role of government and association support. The study of Morais and Franco (2018) examined the effect of domestic market saturation on the internationalization performance.

Although numerous studies have investigated determinants of SMEs internationalization from the internal and external perspective of enterprises, including the role of capabilities from the Resource Based View (RBV) in affecting intention of SMEs to export, these studies focused on the direct effect of capabilities on the intention to export and paid little attention on how SMEs capabilities influence the intention of SMEs to export. Safari and Saleh (2020) asserted that the majority of SMEs internationalization literature tended to focus on the determinants of internationalization decision or performance; only few studies explored mediating factors. Their study investigated the role of innovation strategies, export marketing strategies, and business strategies in mediating the influence of managerial and organizational capabilities as well as external determinants on export performance. A few other studies have also investigated the mediating factors of capabilities and export performance. The study of Ribau et al. (2017) focused on the role of entrepreneurial orientation in mediating the effect of innovation capabilities on export performance of SMEs. Abdulaal and Nordin (2020) theorized that organizational capabilities, i.e. human resources and knowledge management, had impact on SMEs performance through mediating variable of creativity. Due to the lack of study that explores the mediating factors on the relationship between capabilities and internationalization performance, there are numerous novel mediating factors that are potential to be investigated. Agler and De Boeck (2017) stressed the importance of uncovering the relationship between a determinant and an effect in which direct effect left a wide temporal distance that increased the likelihood of unconsidered effect occurrence. This study is intended to disclose the relationship between capabilities and intention to export. According to the theory of Resource Based View (RBV), capabilities and specific assets of enterprise form a fundamental strategy for a unique value creation that provides competitive advantage for an organization (Eisenhardt \& Martin, 2000). The competitive advantage that enterprises possess increases their confidence to deal with the fierce competition in any market either in the domestic market or in the global market. SMEs with distinctive capabilities tend to have more international orientation to search for the potential customers in the global market. Accordingly, internationalization orientation has a potential role in mediating the influence of capabilities on export internationalization. This potential mediation role of internationalization orientation is yet to be studied in literature of SMEs export decision or performance. Therefore, this study provides a contribution to the literature by developing a model that explains how organizational capabilities influence intention to export through internationalization orientation within the context of SMEs.

\section{LITERATURE REVIEW}

\section{Intention to export}

Organization may achieve internationalization through some strategies, particularly through export and foreign direct investments as the most adopted strategies. The internationalization strategy of export has an advantage over foreign direct investment that it is easier and faster in penetrating global markets. Export does not require high commitment such as providing substantial resources, and consequently the level of risk decreases (Golovko \& Valentini, 2011). Considering SMEs have limited resources, export is the most likely way of internationalization for SMEs.

Exporting decision is a complex process that consists of series of stages i.e. export awareness, export intention, export trial, export evaluation, and export acceptance (Reid, 1981). Each stage represents the level of sophistication of organization in export behavior beginning with opportunity recognition in foreign market until export expansion at the last stage. Different dimensions of export behavior involve different performance measures so that usage of common measures for export behavior can be misleading (Reid, 1981). As the majority of SMEs in Indonesia have not involved yet in exporting activities, it was assumed that most of Indonesian SMEs exporting decision is at the export awareness stage or intention stage. Therefore, this study focuses on the intention of SMEs to export.

The concept of intention has been developed in the field of social psychology which explains how attitude and belief of someone influence his behavior (Ajzen \& Fishbein, 1970). According to Ajzen and Fishbein (1970) the prediction of intention is a necessary and sufficient condition for the prediction of behavior. Intention specifies whether a person would or would not perform an act. Reid (1983) described the intention as the likelihood of a person to act particular behavior. Theory of planned behavior asserts that the stronger of intention level the higher of behavior involvement (Ajzen, 1991). The study of Wiodomann et al. (2009) displayed that the intention would be executed through planning an action and was embodied by behavior.

Various studies have adopted the concept of intention, e.g the study of marketingand technology adoption. In the context of internationalization, scholars used the concept to define the intention of internationalization. The intention of an enterprise to go international is not executed instantly, but the company will plan considerately to ensure that the execution of intention brings benefits for the company. Jaffe and Pastemak (1994) defined intention to export as motivation, attitude, belief, and expectation to the contribution of export to the business growth. Intention to export is not 
only a function of organization confidence in the export contribution to the growth, but also the confidence in the superiority dealing with risks.

\section{Internationalization orientation}

The intention of an individual to perform a behavior depends on the belief that the behavior will induce consequences, and whether and how the individual takes an action in a certain condition (Jaffe \& Pastemak, 1994). According to Jaffe and Pastemak (1994), the intention to export was a function of managerial belief, organization readiness, and risk perception toward internationalization. The degree of individual belief affects his intention to perform an action such as in the case of entrepreneurship, the belief of individual in innovating will increase his intention to be an entrepreneur (Ashourizadeh \& Chavoushi, 2014).

Internationalization orientation is an important aspect in business internationalization that requires innovative and proactive attitudes (Acosta et al., 2018). The comprehension of internationalization orientation can be traced to the idea of Knight and Cavusgil (2004) that describes internationalization orientation as the innovativeness of enterprise in pursuing the international market (Acosta et al., 2018). Freeman and Cavusgil (2007) extended the concept by integrating the attitude of management to the risk into the concept. The enterprise that possesses the high degree of innovativeness tends to have strong belief in dealing with the international competition. Management beliefs about firm competitive advantages influence the decision of export (Jaffe \& Pastemak, 1994).

\section{Capabilities}

Resource-based view theorized that organization resources as a competitive advantage source for organization. Warnerfelt (1984) defined organization resources at a particular time point as tangible and intangible assets that were bound to the company semi permanently such as brand, knowledge, trained staff, efficient procedure, and capital. According to Warnerfelt (1984) an organization can keep its unique resources as a relative competitive advantage over its competitors along it takes action rationally. To make organization resources as a competitive advantage, the organization need to create its resources to be inimitable. Valuable and rare resources provide organization competitive advantage temporarily and it will last for a long time so long as the organization protects its resources against imitation, transfer, and substitution of resources. The theory of resource based view establishes a clear association between resources and sustainable competitive advantages (Wade \& Hulland, 2004).

Resources of organization consist of assets as a technology-based resource and capabilities as a system-based resource (Day, 2000; Eisenhardt \& Martin, 2000; Wade \& Hulland, 2004). Assets encompass tangible things such as hardware and intangible things such as software. Competitors tend to imitate this component of resources easily so that it is hard to utilize assets as a sustainable competitive advantage. Capabilities embrace skills such as technical and managerial abilities and processes such as system development. Capabilities are resources that provide organization a sustainable competitive advantage and drive organization to achieve a superior performance. This component of resources is created through capabilities development in the long time period and attached to the organization so that it is difficult to be imitated.

\section{RESEARCH FRAMEWORK AND HYPOTHESIS DEVELOPMENT}

\section{Research Framework}

The research framework was developed based on the resource-based view (RBV) theory. The theory emphasizes on specific capabilities and assets of organization as main determinants of organization's performances (Teece et al., 1997). An organization should harness its resources to obtain competitive advantage by creating a unique value for customers (Eisenhardt \& Martin, 2000). Based on the resource-based view, SMEs which possess unique capabilities as a weapon for competing in the market tend to have the high degree of confidence in dealing with competition. Capabilities of organization can enhance competitiveness by delivering superior product or service (Wang et al., 2020). The study of (Jaffe \& Pastemak, 1994) displayed that management's belief in possessing critical successful skills for running business abroad increased management's motivation to export. Therefore, this study posit that the SMEs with high capabilities tend to have international orientation that look international market as a potential driver for their business growth.

An organization has various capabilities in carrying required activities out in order to deliver a superior value to its customers. Among these capabilities there are only a few of them which potential to provide competitive advantage for the organizational (Day, 2000; Wade \& Hulland, 2004). According to Sarwono (2015) in dealing with the competition SMEs must possess capabilities to design product creatively, produce any kinds of excellent product consistently, ensure the continuity of production, and develop the knowledge and experience. The study of Handoyo et al. (2021) revealed that the critical success factors for SMEs to compete in international level encompass knowledge of foreign markets, capabilities in creating attractive and varied product design. Therefore, crucial capabilities of SMEs encompass capabilities in product innovation, capabilities in production, and capabilities in personnel management. Figure 1 displays the proposed framework of intention to export from the perspective of resource-based view. 


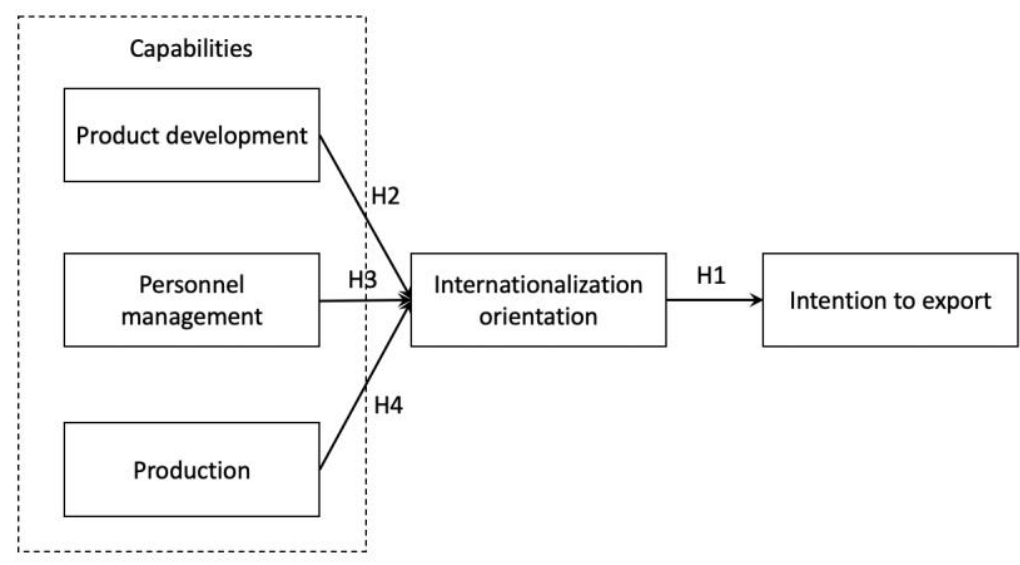

Figure 1. The framework of intention to export.

\section{Hypothesis Development}

\section{Internationalization orientation and intention to export}

The study of Knight (2000) revealed that internationalization orientation associated positively with the internationalization preparation which finally affected firm performance. A firm will have better performance in the international market when the firm is innovative, proactive, and dare to take risks (Acosta et al., 2018). According to Slater (1995) entrepreneurship orientation drives to market-oriented behavior that enable the firm to carry out improvements, overcome its competitors, and take the risks. The study of Ripolles (2012) showed the positive impact of entrepreneurship orientation on internationalization orientation. Acosta et al. (2018) displayed that international entrepreneurship orientation affect positively SMEs internationalization orientation.

The above explanations lead us to posit the following hypothesis:

H1: Internationalization orientation has positive impact on the intention to export.

\section{Product development capabilities and internationalization orientation}

Capabilities to innovate enable an organization to offer novel and better products that is crucial factor in dealing with the competition. Continuous innovation has an important role for achieving commercial and economic success (Cho \& Pucik, 2005). Innovation becomes the key engine for SMEs to expand their market geographically. Hussain et al. (2020) asserted that innovation was the most powerful sources of firms performance and it had a strong influence on market orientation. The study of Golovko and Valentini (2011) showed that innovative firms tended to use its competitive advantage by expanding its market to global market as a strategy to increase the sales. According to Bodlaj et al. (2020) innovative smaller firms can exploit opportunities in overseas markets effectively and firms which master various types of innovation tend to perform better. Innovation has various meanings, in the conctext of product development Saha et al. (2021) defined innovation as the comptetence of a firm in developing new products or improving existing products.

The firm that possesses capabilities in designing unique as well as attractive products has competitive advantage that is hard to be imitated by competitors. According to Styles and Ambler (1994) the quality and uniqueness of product that the firm offers to the market gives significant contribution to the success of business. The unique design of product provides the firm a weapon for competing in international market and increases the belief in dealing with international competition (Michael et al., 2016). The study of Leonidou et al. (2007) showed that small enterprises that possess unique products highly affect their confidence in facing the competition in the global market, subsequently they have motivation to market their products abroad (Leonidou et al., 2007). Ribau et al. (2017) revealed that R\&D capabilities have impact of SMEs export performance through entrpreunial orienation.

\section{Personnel management capabilities and internationalization orientation}

The type of personnel of organization has an important impact on the success of internationalization at any stage in the internationalization process (Welch \& Luostarinen, 1988). On the stage of initial exporting the background of the manager, education and language proficiency has contribution to increase SMEs motivation to go to international. According to Michael et al. (2016) on the initial phase of internationalization process, the firm have to prepare its human resources such as knowledge, skills, and appropriate values so that they have abilities in providing important information for the firm to export its products to abroad.

The importance of human resources in the internationalization process has been highlighted by scholars. The study of Serra et al. (2012) showed that the manager education level had an important role in driving the firm to look the international market as its marketing target. The other study of Cerrato and Piva (2012) had the similar result with the previous study which revealed that human capital had positive impact on internationalization. The study of Ribau et al. (2017) concluded that entrepreneurial orientation mediated the effect of capabilities in adjusting organization structure flexibly on export perfomance of SMEs. 


\section{Production capabilities and internationalization orientation}

The capabilities of SMEs in producing high quality products with the adequate production capacity contribute to build the confidence in competing with any competitors. The study of Leonidou et al. (2007) exhibited that SMEs capabilities of production such as capabilities in providing a large production capacity and reaching the economy of scale induce SMEs to carry out internationalization related activities. The firm which has capabilities in improving production process continuously has an important role in increasing firm's operational performance such as a higher quality. Quality, cost, and delivery are critical success factors for winning the competition, therefore the firm which has capabilities to deliver its products in high quality, competitive price, and fast delivery tends to have wider market perspective not only in the local market, but also the global market. The important role of production capabilites in achieving SMEs performance was shown by the work of Lee et al. (2020). Their study explains that SMEs need to build the technical and technological capacity for improving the efficiency and quality of works. According to Ribau et al. (2017) manufacturing capability is one of SMEs rare and valued capabilities that has impact on export performance. Their study displayed that the influence of manufacturing capability on export performance was mediated by entrepreneurial orientation.

According to the above explanation of the role of organizational capabilities in the internationalization process, this study proposes the following hypotheses:

H2a: SMEs capabilities in developing product have positive impact on internationalization orientation.

$\mathrm{H} 2 \mathrm{~b}$ : Internationalization orientation mediates the effect of SMEs capabilities in developing product and export intention.

H3a: SMEs capabilities in managing personnel have positive impact on internationalization orientation.

H3b: Internationalization orientation mediates the effect of SMEs capabilities in managing personnel and export intention. H4a: SMEs capabilities in producing product have positive impact on internationalization orientation.

$\mathrm{H} 4 \mathrm{~b}$ : Internationalization orientation mediates the effect of SMEs capabilities in producing product and export intention.

\section{METHODOLOGY}

\section{Instrument}

This study developed instrument to measure each variable by defining each variable operationally and determining relevant indicators for each instrument. The measurement instrument involved questionnaires that was developed from various sources. Table 1 displays the measurement instrument in this study.

Table 1. Operational definition and measurement indicators.

\begin{tabular}{ll}
\hline Variable & $\begin{array}{l}\text { Operational } \\
\text { definition }\end{array}$ \\
\hline $\begin{array}{l}\text { Intention to Export } \\
\text { EI) }\end{array}$ & $\begin{array}{l}\text { Degree of } \\
\text { motivation, } \\
\text { attitudes, beliefs, } \\
\text { and expectations in } \\
\text { export contribution } \\
\text { to the firm growth. }\end{array}$ \\
$\begin{array}{l}\text { Internationalization } \\
\text { orientation (IO) }\end{array}$ & $\begin{array}{l}\text { Degree of firm's } \\
\text { innovativeness and } \\
\text { proactiveness in } \\
\text { pursuing } \\
\text { international } \\
\text { market. }\end{array}$ \\
&
\end{tabular}

Personnel management (PM)
Firm capabilities in developing good quality personnel and adequate number of personnel.
1. Commitment/intention of company to export related activities.

2. Effort of company to find ways to market abroad.

3. Interest of company to build a relationship with foreign partners.

1. Firms' possession of export Bagheri et al. (2019) related information.

2. Frequency of firm's participation in international exhibition regularly.

3. Time availability of firm's leader for going abroad.

4. Searching international client's contact actively.

5. Monitoring international market dynamics regularly.

1. The experience of personnel in Omri and Becuwe (2014) the related field.

2. The English proficiency of personnel.

3. Delivering effective training for personnel.

4. The availability of adequate personnel.

5. The knowledge of personnel in export activities.

Jaffe and Pastemak (1994)




\begin{tabular}{|c|c|c|c|}
\hline Variable & $\begin{array}{l}\text { Operational } \\
\text { definition }\end{array}$ & Indicators & Sources \\
\hline $\begin{array}{l}\text { Product } \\
\text { development (PD) }\end{array}$ & $\begin{array}{l}\text { Firm capabilities in } \\
\text { developing unique } \\
\text { and innovative } \\
\text { products. }\end{array}$ & $\begin{array}{l}\text { 1. The introduction of new } \\
\text { products to market. } \\
\text { 2. Offering unique products to } \\
\text { customers. } \\
\text { 3. Developing innovative } \\
\text { products. } \\
\text { 4. Modifying existing products. }\end{array}$ & Bagheri et al. (2019) \\
\hline Production (PR) & $\begin{array}{l}\text { Firm capabilities in } \\
\text { producing products } \\
\text { with high quality } \\
\text { standard and great } \\
\text { flexibility. }\end{array}$ & $\begin{array}{l}\text { 1. The adequate production } \\
\text { capacity. } \\
\text { 2. Master's in production } \\
\text { technology. } \\
\text { 3. Adopting the production } \\
\text { technology. } \\
\text { 4. Improving production process } \\
\text { and technique regularly. }\end{array}$ & Belso-Martinez (2006) \\
\hline
\end{tabular}

\section{Data collection}

The study was confined to enterprises that operated within fashion industries and located in the Bandung area as one of fashion industry centers in Indonesia. The analysis unit was a company that met the criteria of small and medium enterprises in Indonesia i.e., number of employees, assets, turnovers are no more than 300 people, 10 billion, 50 billion rupiahs respectively. The eligible respondent was the representative of company who possessed internal and external knowledge of company such as the owner, director, or manager. This study collected data through an online survey by sending the questionnaires through emails or social medias, as well as an offline survey by visiting the location of respondents for three months. The total number of returned questionnaires were 93 questionnaires and 7 of them were not eligible. Thus, there were 86 eligible samples to be used for examining the proposed model.

All questions either questions of dependent variables, i.e., intention to export and internationalization orientation, or questions of independent variables, i.e., personnel management, product development, and production were responded by the same person. According to (Podsakoff et al., 2003) rating the independent and independent variables by the same person can induce common method bias that influences the accuracy of observed correlation. Therefore, it is important to examine the existence of common method bias in the study and the most used technique for examining the bias is Harman's single-factor test (Podsakoff et al., 2003). The test includes all variables in the exploratory factor analysis and examines the unrotated factor solution to determine the number of factors that are required for explaining the variance of variables. If the result shows that there is one explaining factor for most of data variances, then the common method bias exists in the study. All variables were examined through factor analysis and the result indicated that one factor explained $42.57 \%$ variances below the threshold of $50 \%$. Therefore, it was concluded that there was no common method bias in this study.

Respondents who involved in the study came from various company characteristics. Most of companies had experience in the business more than 10 years, number of employees less than 30 people, turnover per year less than 2.5 billion rupiahs, owned by family. The characteristics of respondents were dominated by male, above 30 years old, and having senior higher school education or below. Table 2 displays the company and respondent profile.

Table 2. Company and respondent profile.

\begin{tabular}{|c|c|c|c|c|}
\hline No. & \multicolumn{2}{|c|}{ Company and respondent profile } & Frequency & Percentage \\
\hline \multirow{2}{*}{1} & \multirow{2}{*}{ Company age } & $\leq 10$ years & 23 & 17.44 \\
\hline & & $>10$ years & 63 & 73.26 \\
\hline \multirow{2}{*}{2} & \multirow{2}{*}{$\begin{array}{l}\text { Number of } \\
\text { employees }\end{array}$} & $\leq 30$ employees & 51 & 59,30 \\
\hline & & > 30 employees - 300 employees & 35 & 40.70 \\
\hline \multirow[b]{2}{*}{3} & \multirow[b]{2}{*}{ Turnover per year } & $\leq 2.5$ billion rupiahs & 63 & 73.26 \\
\hline & & $\begin{array}{l}>2,5 \text { billion rupiahs - } 50 \text { billion } \\
\text { rupiahs }\end{array}$ & 23 & 26.74 \\
\hline \multirow{2}{*}{4} & \multirow{2}{*}{ Location } & Industrial area & 40 & 46.51 \\
\hline & & Nonindustrial area & 46 & 53.49 \\
\hline \multirow{2}{*}{5} & \multirow{2}{*}{ Ownership } & Family & 80 & 93.02 \\
\hline & & Nonfamily & 6 & 6.98 \\
\hline \multirow{2}{*}{6} & \multirow{2}{*}{ Gender } & Male & 60 & 69.77 \\
\hline & & Female & 26 & 30.23 \\
\hline 7 & Age of respondent & $<30$ years & 16 & 18.60 \\
\hline
\end{tabular}




\begin{tabular}{ccrrr}
\hline No. & Company and respondent profile & Frequency & Percentage \\
\hline & & $30-39$ years & 22 & 25.58 \\
& & $40-49$ years & 18 & 20.93 \\
& & $\geq 50$ years & 30 & 34.88 \\
\multirow{2}{*}{8} & Education of & Senior high school or below & 48 & 55.81 \\
& respondent & Bachelor or above & 38 & 44.19 \\
\hline
\end{tabular}

\section{Model examination}

The proposed model was examined usingstructural equation modeling (SEM) technique.. SEM technique has the capability in analyzing the model of relationship between multi independent and dependent constructs simultaneously (Gefen et al., 2000). There are two types of SEM technique i.e., covariance analysis (CB-SEM) that is intended for showing that all determined paths in a model can be accepted based on the sample data, and partial least squares (PLSSEM) that has the function for showing a high degree of $\mathrm{R}^{2}$ and significant $\mathrm{t}$-value. The study used partial least squared - structural equation modeling (PLS-SEM) considering the characteristics of the study as follow: 1) predictive study i.e., the study intended to predict SMEs internationalization through export their products to the international market; 2) new theory in the study i.e., capabilities of enterprises influenced SMEs international orientation that finally impacted their intention to export. According to (Gefen et al., 2000) PLS-SEM is suitable for predicting the impact of independent variable on dependent variable, and analyzing the new theory because the technique is designed to explain the significance of relationship and resulted $\mathrm{R}^{2}$.

PLS-SEM offers the advantage of its capabilities in analyzing a model using a small number of samples (Gefen et al., 2000). Most of previous studies used this technique due to their limited number of samples in their study (Hair, Sarstedt, et al., 2014). There is no consensus of sample number determination, Falk and Miller (1992) stated that there are three streams in determining the sample number i.e., the conservative stream, it believes that the minimum sample number equals to 10 samples for each variable; the liberal stream, it advocates that 2 samples for each variable are satisfied; the moderate stream, it suggests to use the 5:1 ratio. Falk and Miller (1992) suggest using the 5:1 ratio for analyzing the PLS model. Meanwhile Hair, Sarstedt, et al. (2014) advice to use rule of thumb in determining the minimum sample number for analyzing the PLS model i.e., minimum 10 times of the largest number of formative indicators or 10 times of the largest number of structural paths toward a particular construct. Our study involved 3 paths toward a particular variable i.e., international orientation as the largest number of structural paths. Based on Hair, Sarstedt, et al. (2014) suggestion, it needed at least 30 samples for analyzing the proposed model. This study had 86 samples above the minimum sample number requirement.

Although there is a limited number of samples, PLS-SEM still has the capability to analyze the model effectively because the technique analyzes a construct through implementing iterative sequences of ordinary least squares and multiple linear regressions at one time (Gefen et al., 2000). PLS-SEM implements the approach of bootstrapping which does not require parametric assumptions to estimate the significance of relationships. Therefore, PLS-SEM is suitable for analyzing a limited number of samples and non-normal distributions (Gefen et al., 2000). PLS-SEM can result in the best predictive weights set from any sample distributions because PLS uses the procedure based on least square methods in providing unbiased estimations with minimum variances (Falk \& Miller, 1992). PLS-SEM uses central limit theorem to transform non-normal data, therefore it can work effectively on the non-normal distribution (Hair, Sarstedt, et al., 2014).

According to the above explanations, it was appropriate to use PLS-SEM in examining the proposed model. Figure 2 displays the PLS model that describes the relationship between endogen and exogen variables. The model examination consisted of two main stages namely the examination of measurement model and structural model.

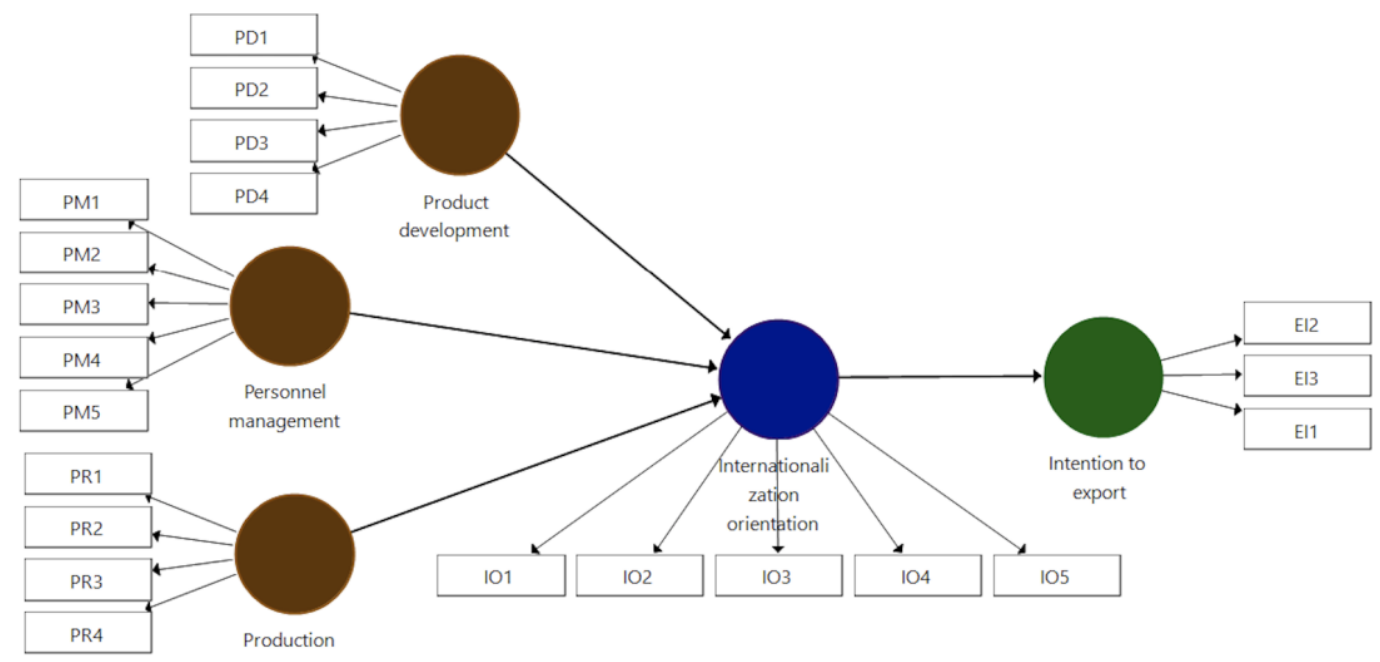

Figure 2. PLS model of intention to export. 


\section{Measurement model examination}

Hair, Hult, et al. (2014) suggest evaluating measurement model based on the criteria of composite reliability to examine the internal consistency reliability, outer loading and average variance extracted (AVE) to evaluate the convergent validity, and Fornel-Larcker values to assess the discriminant validity. This study evaluated the measurement model based on those criteria of goodness of measurement model. The value of composite reliability varies between 0 and 1 with the higher value indicates the higher reliability. The level of composite reliability that considered satisfied is at range of $0.7-0.9$. The value of outer loadings is expected at least 0.708 . The threshold of AVE is 0.5 that indicates the construct explaining more than a half of indicators variance. The criterion of Fornel-Larcker is evaluated through the comparison between the square root of AVE of a particular variable and the value of its correlations with other variables. The square root of AVE of a particular variable must be larger than the highest its correlation with other variables. Table 3 and 4 display the results of measurement model examination.

Table 3. Factor loading, composite reliability, and AVE of the intial measurement model.

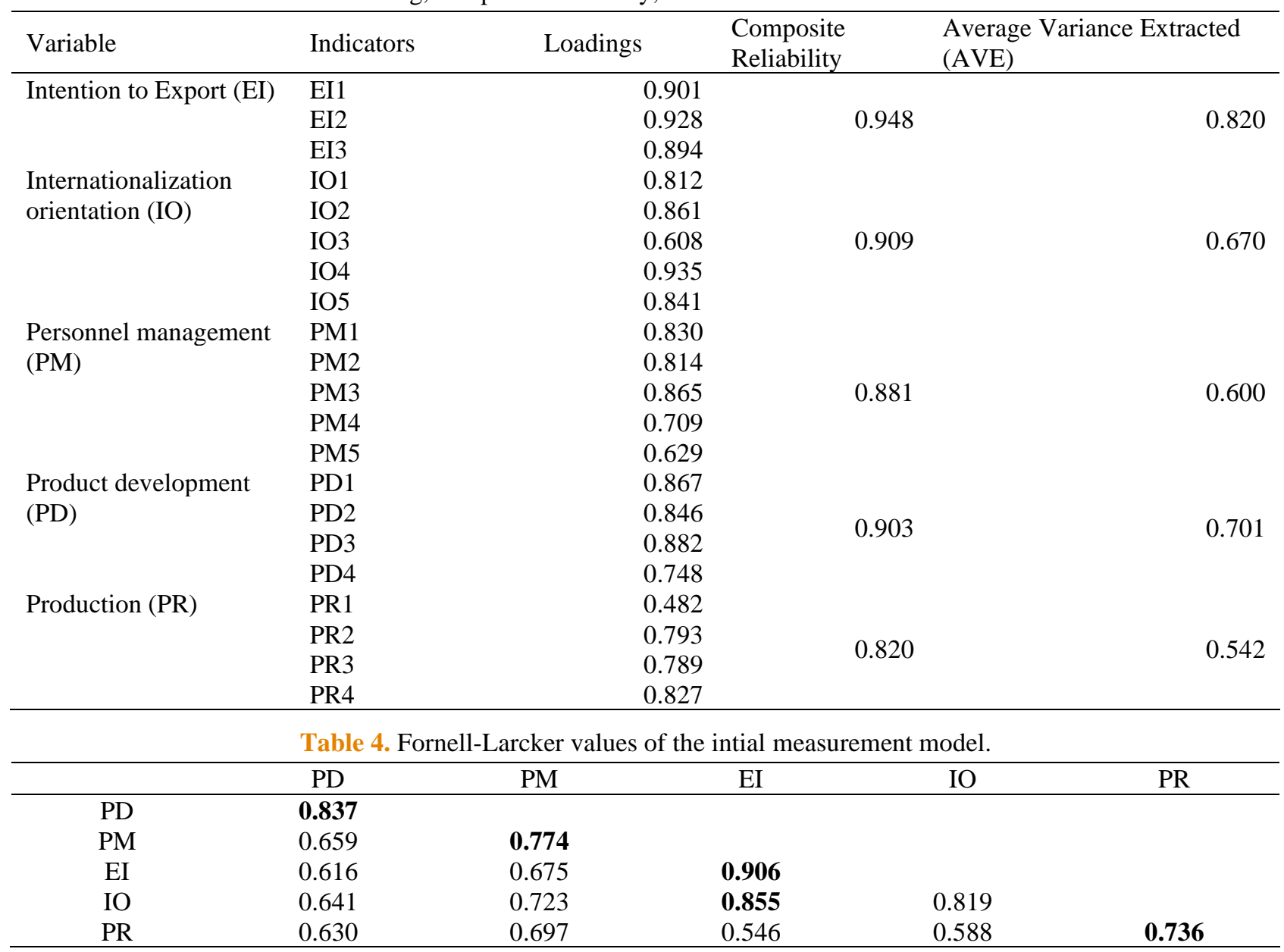

The outer loading of IO3 and PR1 was below the threshold of 0.7 and the square root of IO AVE of 0.819 is below the highest IO correlation with other variables (EI) of 0.855 . Therefore, the measurement model had not met the convergent and discriminant validity criteria. the measurement model was rectified by eliminating indicators IO3 and PR1 from the model and reexamining the rectified measurement model. Table 5 and 6 show results of the rectified measurement model examination.

Table 5. Factor loading, composite reliability, and AVE of the rectified measurement model.

\begin{tabular}{llrrr}
\hline Variable & Indicators & Loadings & $\begin{array}{c}\text { Composite } \\
\text { Reliability }\end{array}$ & $\begin{array}{l}\text { Average Variance Extracted } \\
\text { (AVE) }\end{array}$ \\
\hline Intention to Export (EI) & EI1 & 0.901 & 0.948 & 0.820 \\
& EI2 & 0.928 & & \\
Internationalization & IO1 & 0.895 & & 0.763 \\
orientation (IO) & IO2 & 0.797 & 0.928 & \\
& IO4 & 0.891 & & 0.600 \\
Personnel management & IO5 & 0.935 & & \\
PM) & PM2 & 0.864 & 0.881 &
\end{tabular}




\begin{tabular}{|c|c|c|c|c|}
\hline Variable & Indicators & Loadings & $\begin{array}{l}\text { Composite } \\
\text { Reliability }\end{array}$ & $\begin{array}{l}\text { Average Variance Extracted } \\
\text { (AVE) }\end{array}$ \\
\hline \multirow{7}{*}{$\begin{array}{l}\text { Product } \\
\text { (PD) }\end{array}$} & PM3 & 0.863 & \multirow{7}{*}{0.903} & \multirow{7}{*}{0.701} \\
\hline & PM4 & 0.708 & & \\
\hline & PM5 & 0.633 & & \\
\hline & PD1 & 0.867 & & \\
\hline & PD2 & 0.845 & & \\
\hline & PD3 & 0.881 & & \\
\hline & PD4 & 0.749 & & \\
\hline \multirow[t]{3}{*}{ Production (PR) } & PR2 & 0.797 & & \\
\hline & PR3 & 0.806 & 0.858 & 0.669 \\
\hline & PR4 & 0.850 & & \\
\hline
\end{tabular}

Table 6. Fornell-Larcker values of the rectified measurement model.

\begin{tabular}{cccccc}
\hline & PD & PM & EI & IO & PR \\
\hline PD & $\mathbf{0 . 8 3 7}$ & & & & \\
PM & 0.657 & $\mathbf{0 . 7 7 5}$ & & & \\
EI & 0.616 & 0.674 & 0.906 & 0.873 & 0.818 \\
IO & 0.627 & 0.721 & 0.849 & 0.599 & 0.546 \\
PR & 0.608 & 0.678 & 0.896 \\
\hline
\end{tabular}

The final measurement model examination displayed that the measurement model was considered valid and reliable. Hence, the data from the final measurement model was then used to examine the structural model.

\section{Structural model examination}

The purpose of structural model examination is to generalize the results through determining the hypothesis acceptance or rejection. This study followed the steps of structural model examination that consisted of collinearity analysis, relationship significance analysis, and determination analysis.

According to Hair, Hult, et al. (2014) the examination of structural model should be free from the multi-collinearity issue that has impact on the weight and significance estimation. The existence of collinearity increases the error standard that reduces the ability to detect the significance of relationship and results in inaccurate weight estimation. Collinearity can be evaluated from the value of variance inflation factor (VIF) which the value above 5 indicates the existence of collinearity (Hair, Hult, et al., 2014). Table 7 displays the value of VIF and all values below the threshold, therefore there is no collinearity in the structural model.

Table 7. Variance inflation factor (VIF).

\begin{tabular}{|c|c|c|c|c|c|}
\hline & $\mathrm{PD}$ & PM & EI & IO & PR \\
\hline PD & & & & 2.043 & \\
\hline PM & & & & 2.381 & \\
\hline EI & & & & & \\
\hline IO & & & 1.000 & & \\
\hline PR & & & & 2.829 & \\
\hline
\end{tabular}

After it was ensured that there was no collinearity issue, the evaluation of structural model was conducted based on the criteria of path coefficient weight and significance, as well as determination coefficient $\left(\mathrm{R}^{2}\right)$. The significance of path coefficient resulted from the bootstrapping process, and the study involved 5000 sub-sample in the bootstrapping process. The examination displayed that all structural relationships were significant at the 0.05 significance level, except the relationship between production and internationalization orientation. Table 8 shows the significance of structural relationships.

Table 8. Significance of structural relationships.

\begin{tabular}{|c|c|c|c|c|c|c|}
\hline Hypotheses & & & $\begin{array}{l}\text { Path } \\
\text { Coefficients }\end{array}$ & t-Statistics & P-Values & Conclusions \\
\hline $\mathrm{H} 1$ & $\begin{array}{l}\text { Internationalization } \text { Orientation } \\
\text { Intention to Export }\end{array}$ & $->$ & 0.855 & 23.972 & 0.000 & Supported $* * *$ \\
\hline $\mathrm{H} 2 \mathrm{a}$ & $\begin{array}{l}\text { Product } \quad \text { Development } \\
\text { Internationalization Orientation }\end{array}$ & $->$ & 0.226 & 2.121 & 0.034 & Supported $* *$ \\
\hline $\mathrm{H} 3 \mathrm{a}$ & $\begin{array}{l}\text { Personnel Management } \\
\text { Internationalization Orientation }\end{array}$ & $->$ & 0.500 & 4.745 & 0.000 & Supported $* * *$ \\
\hline $\mathrm{H} 4 \mathrm{a}$ & $\begin{array}{l}\text { Production } \rightarrow \text { Internationalizatic } \\
\text { Orientation }\end{array}$ & & $-0,059$ & 0.491 & 0.624 & Not supported \\
\hline
\end{tabular}




$$
* * * \quad \text { : significance level of } 0.01 ; \quad * * \quad: \text { significance level of } 0.05
$$

Determination coefficient denotes the accuracy of predictive of model which represents the degree of endogen construct variance explained by all exogen constructs. Table 9 displays the determination coefficients of endogen constructs. The construct of internationalization orientation had the value $\mathrm{R}^{2}$ of 0.729 near the substantial threshold of 0.75 , and the value $\mathrm{R}^{2}$ of internationalization orientation was at the level of 0.576 . The results indicated that the model had moderate level of the predictive accuracy.

Table 9. The value of $\mathrm{R}^{2}$.

\begin{tabular}{lcc}
\hline Endogen Variables & $\mathrm{R}$ square & $\mathrm{R}$ square adjusted \\
\hline Intention to Export & 0.732 & 0.729 \\
Internationalization Orientation & 0.600 & 0.576 \\
\hline
\end{tabular}

Total effect of exogen variables (product development, personnel management, production) to endogen variables (intention to export) provides the insights the level of effect of each exogen variable on intention of small medium enterprises to export. Table 10 displays the level of total effect of exogen variables.

Table 10. Total effect.

\begin{tabular}{lrrr}
\hline Relationships & Level of Effect & t-Statistics & \multicolumn{2}{c}{ P-Values } \\
\hline $\begin{array}{l}\text { Product Development -> Intention to Export } \\
\text { Product Development -> Internationalization }\end{array}$ & 0.193 & 2.076 & 0.038 \\
$\begin{array}{l}\text { Orientation } \\
\text { Personnel Management -> Intention to Export }\end{array} \quad 0.226$ & 0.427 & 2.121 & 0.034 \\
$\begin{array}{l}\text { Personnel Management -> Internationalization } \\
\text { Orientation }\end{array}$ Internationalization Orientation -> Intention to & 0.500 & 4.745 & 0.000 \\
$\begin{array}{l}\text { Export } \\
\text { Production -> Intention to Export }\end{array}$ & 0.855 & 23.972 & 0.000 \\
Production -> Internationalization Orientation & -0.050 & 0.489 & 0.000 \\
\hline
\end{tabular}

Lastly, this study examined the mediating effect of internationalization orientation on the relationship of capabilities and intention to export. There are several steps to analyze the mediating effect, i.e., evaluating significance of the direct effect of capabilities on intention to export without including the mediator variable; assessing significance of the indirect effect that is the effect of capabilities on internationalization orientation and the effect of internationalization on intention to export; and the last step is assessing the variance accounted for (Hair, Hult, et al., 2014). Table 11 displays the results of the mediating effect examination by following these steps.

Table 11. Mediating effect of internationalization orientation.

\begin{tabular}{|c|c|c|c|c|c|}
\hline Direct Relationship & $\begin{array}{l}\text { Significance of } \\
\text { Direct Effect }\end{array}$ & $\begin{array}{l}\text { Indirect } \\
\text { Relationship }\end{array}$ & $\begin{array}{l}\text { Significance of } \\
\text { Indirect Effect }\end{array}$ & $\begin{array}{l}\text { Variance } \\
\text { Accounted For } \\
\text { (VAF) }\end{array}$ & Conclusions \\
\hline $\begin{array}{l}\text { Product } \\
\text { Development -> } \\
\text { Intention to Export }\end{array}$ & $\begin{array}{l}\text { Effect: } 0.193 \\
\text { P-values: } 0.038\end{array}$ & $\begin{array}{l}\text { Product } \\
\text { Development -> } \\
\text { Internationalization } \\
\text { Orientation } \\
\text { Internationalization } \\
\text { Orientation -> } \\
\text { Intention to Export }\end{array}$ & $\begin{array}{l}\text { Effect: } 0.226 \\
\text { P-values: } 0.034 \\
\text { Effect: } 0.855 \\
\text { P-values: } 0.000\end{array}$ & 0.500 & $\begin{array}{l}\mathrm{H} 2 \mathrm{~b} \text { is } \\
\text { supported. } \\
\text { International } \\
\text { ization has a } \\
\text { mediation } \\
\text { effect }\end{array}$ \\
\hline $\begin{array}{l}\text { Personnel } \\
\text { Management -> } \\
\text { Intention to Export }\end{array}$ & $\begin{array}{l}\text { Effect: } 0.427 \\
\text { P-values: } 0.000\end{array}$ & $\begin{array}{l}\text { Personnel } \\
\text { Management -> } \\
\text { Internationalization } \\
\text { Orientation } \\
\text { Internationalization } \\
\text { Orientation -> } \\
\text { Intention to Export }\end{array}$ & $\begin{array}{l}\text { Effect: } 0.500 \\
0.000 \\
\text { Effect: } 0.855 \\
\text { P-values: } 0.000\end{array}$ & 0.500 & $\begin{array}{l}\mathrm{H} 3 \mathrm{~b} \text { is } \\
\text { supported. } \\
\text { International } \\
\text { ization has a } \\
\text { mediation } \\
\text { effect }\end{array}$ \\
\hline $\begin{array}{l}\text { Production -> } \\
\text { Intention to Export }\end{array}$ & $\begin{array}{l}\text { Effect: }-0.050 \\
\text { P-values: } 0.625\end{array}$ & $\begin{array}{l}\text { Production -> } \\
\text { Internationalization } \\
\text { Orientation } \\
\text { Internationalization } \\
\text { Orientation -> } \\
\text { Intention to Export }\end{array}$ & $\begin{array}{l}\text { Effect: }-0.059 \\
\text { P-values: } 0.624 \\
\text { Effect: } 0.855 \\
\text { P-values: } 0.000\end{array}$ & - & $\begin{array}{l}\text { H4b is not } \\
\text { supported. } \\
\text { No } \\
\text { mediating } \\
\text { effect in } \\
\text { which the }\end{array}$ \\
\hline
\end{tabular}




\begin{tabular}{|c|c|c|c|c|c|}
\hline Direct Relationship & $\begin{array}{l}\text { Significance of } \\
\text { Direct Effect }\end{array}$ & $\begin{array}{l}\text { Indirect } \\
\text { Relationship }\end{array}$ & $\begin{array}{l}\text { Significance of } \\
\text { Indirect Effect }\end{array}$ & $\begin{array}{l}\text { Variance } \\
\text { Accounted For } \\
\text { (VAF) }\end{array}$ & Conclusions \\
\hline & & & & & $\begin{array}{l}\text { direct effect } \\
\text { is not } \\
\text { significant }\end{array}$ \\
\hline
\end{tabular}

\section{DISCUSSIONS}

According to the empirical results described in the previous section, the intention to export of SMEs was influenced by the extent of enterprise's proactiveness in running the business with international perspective. The results revealed that the enterprise which actively searched information of international market, participated in international exhibitions, and searched potential international clients tended to have higher intention to export. The knowledge of international market enabled the firm to assess the potential risks and the benefits from entering the global market. The likely to enter the global market was higher when the firms perceived that the potential benefits, they would gain from international market were larger than the risks. According to Leonidou et al. (2007) the potential economic benefit from export strongly affected the enterprise to export. The firms also would identify the sources of risks and took necessary measures to ensure their readiness for internationalization. Therefore, the firms with high internationalization orientation tended to have the readiness to enter the international market, and finally encourage them to compete globally. The results of our study aligned with the study of Ashourizadeh and Chavoushi (2014) in the context of entrepreneurships. They found that the intention of people to run their own business was influenced by the proactiveness in self development as a source of innovation.

The results of this study that internationalization orientation had a mediating role for the relationship between capabilities of organization and the intention to export,. This finding supported this study in disclosing the relationship between capabilities and intention to export and explaining how the organizational capabilities influence the export intention of enterprise. Th results displayed that the capabilities of SMEs in managing their personnel have significant impact on internationalization orientation. The firms which had experienced and well-educated personnel, as well as personnel with international language proficiency and understanding in export activities were apt to have high confidence in competing with the local or international competitors. The possession of good personnel played an important role for creating the quality of works in the value chains of organization from designing until delivering the products to the customers. The enterprises could exploit their strengths to boost their sales by expanding their market to global market. To reach the international market, the firms needed international-oriented management to manage the organization. What was found in this study was consistent with the results of previous studies. The study of Serra et al. (2012) displayed the similar results with ours regarding the significance of personnel quality with the intention to export. According to their study there was a significant impact of manager's education on intention of the enterprise to export. The other study of Cerrato and Piva (2012) also showed the similar results which there was a positive influence from human resources on internationalization. The results of our study have a similarity with the study of Ribau et al. (2017) which found that the capability in adjusting organization structure influenced export performance of SMEs indirectly through entrepreneurial orientation as a mediating factor.

The capabilities in developing unique and innovative products increased the confidence of SMEs in facing the intense competition. The quality of product with appealing design is one of key factors to compete in the market and attract customers to make a business deal. Based on our study, the enterprises which possessed the capabilities in product design and development tended to have intention to export through international orientation in managing their business such as searching the foreign market opportunities or participating in the international fair. SMEs confidence of their products encouraged them to penetrate global market, and to offer their products to international customers. Therefore, the impact of product development capabilities on export intention of SMEs is mediated by international orientation. Our result aligned with the study of Ribau et al. (2017) which showed the indirect effect of R\&D capability on export performance of SMEs through entrepreneurial orientation. The results of our study were similar to the results of Michael et al. (2016) which displayed that the enterprises used unique product design as leverage to enter the international market.

This study also obtained unexpected result which was different from the hypothesis. Production was found to have an insignificant influence on international orientation and intention to export. Meanwhile, the study of Leonidou et al. (2007) disclosed that the production capabilities, particularly capabilities in providing the sufficient production capacity, had high impact on export. The finding was also not align with the study of Ribau et al. (2017) which revealed the significant impact of manufacturing capability on export performance of SMEs. These contrary results could come from the samples from textile and garment enterprises, in which the practice of outsourcing was a common strategy to achieve cost-effective production, regardless of the production capacity. When the enterprises have a limited production capacity, they deal with the shortage of capacity by outsourcing their production processes to other enterprises.

\section{CONCLUSION, LIMITATIONS AND SUGGESTIONS FOR FUTURE STUDY}

\section{Conclusion}

This study investigated the role of internationalization orientation as a mediator of the relationship between capabilities of SMEs and their export intention. The SMEs that had the high capabilities in product development and 
personnel management tended to have high degree intention to export due to their confidence in looking the global market as the potential market of their products. According to our research findings, good personnel management indicated by having experienced and knowledgeable personnel in export activities as well as international language proficiency was a rare capital that supported SMEs to enter an international market. In addition, SMEs looked the global market as their potential market when they had capabilities in creating unique, attractive, and quality products that could be accepted well by global customers. These capabilities encouraged the firms to orient themselves to the international level through searching international customers or participating in international exhibitions. The higher SMEs exposed by the international affairs the higher they had an intention to export. This study enhanced the theory of internationalization by building a theoretical model to comprehend how organizational capabilities influenced firms to look an international market as their market expansion in the context of SMEs. To our knowledge, the study is the first attempt to explain how SMEs capabilities influence the intention to export through internationalization orientation.

Our study suggests that to boost the contribution of SMEs in national export, they must have international orientation which enables them to identify opportunities in the global market. To enhance their orientation to international market, the firms must develop the capabilities in managing the personnel and developing the product. The SMEs should focus on increasing their personnel's export knowledge as well as international language skill. Therefore, it is important to train firm's personnel either through participating in training or workshop provided by governments or non-profit institutions, or in internal training provided by themselves. SMEs also must make the effort to provide unique and innovative products, modify their existing products consistently or introduce the new products. It requires them to have creativity and generate ideas of products. They can benchmark the product design from other companies or collaborate with larger enterprises in product design.

\section{Limitations and Suggestions for Future Study}

We had some limitations that could be followed up in the next studies. Firstly, this study used the cross-sectional strategy that captured the phenomena at one time which assumed all variables occurred simultaneously. The occurrence of capabilities did not trigger internationalization orientation instantaneously. There was a time function to analyze the impact of capabilities on internationalization orientation, and finally the intention to export. Therefore, to obtain more precise results, the future studies can adopt the longitudinal strategy or case studies method to analyze the relationship between variables. Secondly, the study involved a limited number of samples that increased the risk to obtain less precise model parameter estimation. Thirdly, our study focused on internal aspects of SMEs i.e., the impact of capabilities on intention to export. Due to the limited resources of SMEs, the role of external factors such as government body has an important contribution on developing the SMEs capabilities. Therefore, it will be interesting to investigate the relationship between external factors and internal factors.

\section{REFERENCES}

Abdulaal, A. M., \& Nordin, N. (2020). Review paper: The mediating role of creativity on the relationship between knowledge management and human resources management toward innovation performance in the Jordan SMEs. International Journal of Industrial Management, 8(1), 12-18. https://doi.org/https://doi.org/10.15282/ijim.8.0.2020.5759

Acosta, A. S., Crespo, A. H., \& Agudo, J. C. (2018). Effect of market orientation, network capability and entrepreneurial orientation on international performance of small and medium enterprises (SMEs). International Business Review, 27(6), 1128-1140. https://doi.org/https://doi.org/10.1016/j.ibusrev.2018.04.004

Agler, R., \& De Boeck, P. (2017, 2017-November-15). On the Interpretation and Use of Mediation: Multiple Perspectives on Mediation Analysis [Conceptual Analysis]. Frontiers in Psychology, 8(1984), 1-11. https://doi.org/10.3389/fpsyg.2017.01984

Ajzen, I. (1991). The theory of planned behavior. Organizational Behavior and Human Decision Processes, 50(2), $179-211$. https://doi.org/https://doi.org/10.1016/0749-5978(91)90020-T

Ajzen, I., \& Fishbein, M. (1970). The Prediction of Behavior from Attitudinal and Normative Variables. Journal of Experimental Social Psychology, 6(4), 466-487. https://doi.org/https://doi.org/10.1016/0022-1031(70)90057-0

Ashourizadeh, S., \& Chavoushi, Z. H. (2014). People's confidence in innovation: A component of the entrepreneurial mindset, embedded in gender and culture, affecting entrepreneurial intention. International Journal Entrepreneurship and Small Business, 23(1/2), 235-251. https://doi.org/10.1504/IJESB.2014.065310

Bagheri, M., Mitchelmore, S., \& Bamiatzi, V. (2019). Internationalization orientation in SMEs: The mediating role of technological Innovation. Journal of International Management, 25(1), 121-139. https://doi.org/https://doi.org/10.1016/j.intman.2018.08.002

Belso-Martinez, J. A. (2006). Do industrial districts influence export performance and export intensity? Evidence for Spanish SMEs' internationalization process. $\quad$ European Planning $\quad$ Studies, $\quad 14(6), \quad$ 791-810. https://doi.org/https://doi.org/10.1080/09654310500496115

Bodlaj, M., Maglajlic, S. K., \& Vida, I. (2020). Disentangling the impact of different innovation types, financial constraints and geographic diversification on SMEs' export growth. Journal of Business Research, 108(C), 466-475. https://doi.org/doi:10.1016/j.jbusres.2018.10.043

Cassiman, B., Golovko, E., \& Martinez-Ros, E. (2010). Innovation, exports and productivity. International Journal of Industrial Organization, 28(4), 372-376. https://doi.org/https://doi.org/10.1016/j.ijindorg.2010.03.005

Cerrato, D., \& Piva, M. (2012). The internationalization of small and medium-sized enterprises: The effect of family management, human capital and foreign ownership. Journal of Management Government, 16(4), 617-644. https://doi.org/https://doi.org/10.1007/s10997-010-9166-x

Chen, H. L., Hsu, W. T., \& Chang, C. Y. (2014). Family ownership, institutional ownership, and internationalization of SMEs. Journal of Small Business Management, 52(4), 771-789. https://doi.org/10.1111/jsbm.12031 
Cho, H. J., \& Pucik, V. (2005). Relationship between innovativeness, quality, growth, profitability, and market value. Strategic Management Journal, 26(6), 555-575. https://doi.org/https://doi.org/10.1002/smj.461

Day, G. S. (2000). Managing market relationships. Journal of the Academy of Marketing Science, 28(1), 24-30. https://doi.org/https://doi.org/10.1177/0092070300281003

Deng, P., \& Zhang, S. (2018). Institutional quality and internationalization of emerging market firms: Focusing on Chinese SMEs. Journal of Business Research, 92, 279-289. https://doi.org/https://doi.org/10.1016/j.jbusres.2018.07.014

Eisenhardt, K. M., \& Martin, J. A. (2000). Dynamic capabilities: What are they? Strategic Management Journal, 21(10/11), 11051121. https://doi.org/https://www.jstor.org/stable/3094429

Falk, R. F., \& Miller, N. B. (1992). A Primer for Soft Modeling. The University of Akron Press.

Francioni, B., Pagano, A., \& Castellani, D. (2016). Drivers of SMEs' exporting activity: a review and a research agenda. Multinational Business Review, 24(1), 194-215. https://doi.org/https://doi.org/10.1108/MBR-06-2016-0023

Freeman, S., \& Cavusgil, S. T. (2007). Toward a typology of commitment states among managers of born-global firms: A study of accelerated internationalization. Journal of International Marketing, $15(4), \quad 1-40$. https://doi.org/https://doi.org/10.1509/jimk.15.4.1

Gefen, D., Straub, D., \& Boudreau, M. C. (2000). Structural Equation Modeling and Regression: Guidelines for Research Practice. Communications of the Association for Information System, 4(7), 1-78. https://doi.org/ https://doi.org/10.17705/1CAIS.00407

Golovko, E., \& Valentini, G. (2011). Exploring the complementarity betweeninnovation and export for SMEs' growth. Journal of International Business Studies, , 42(3), 362-380. https://doi.org/https://www.jstor.org/stable/29789427

Hair, J. F., Hult, G. T. M., Ringle, C. M., \& Sarstedt, M. (2014). A Premier on Partial Least Squares Structural Equation Modeling (PLS-SEM). Sage Publications.

Hair, J. F., Sarstedt, M., Hopkins, L., \& Kuppelwieser, V. G. (2014). Partial least squares structural equation modeling (PLS-SEM): An emerging tool in business research. European Business Review, 26(2), 106-121. https://doi.org/https://doi.org/10.1108/EBR10-2013-0128

Handoyo, S., Yudianto, I., \& Fitriyah, F. K. (2021). Critical success factors for the internationalisation of small-medium enterprises in indonesia. Cogent Business \& Management, 8(1), 20. https://doi.org/https://doi.org/10.1080/23311975.2021.1923358

Hussain, S. R., Hashim, F., \& Jamaludin, M. F. (2020). The moderating effect of directors network towards technological innovation and firms performance: A conceptual Paper. International Journal of Industrial Management, 7(1), 42-51. https://doi.org/https://doi.org/10.15282/ijim.7.0.2020.5753

Jaffe, E. D., \& Pastemak, H. (1994). An attidudinal model to determine the export intention of non-exporting, small manufacturers. International Marketing Review, 11(3), 17-32. https://doi.org/https://doi.org/10.1108/02651339410067030

KemenKopUKM. (2018). Perkembangan Data Usaha Mikro, Kecil, Menengah (UMKM) Dan Usaha Besar (UB). http://www.depkop.go.id/uploads/laporan/1580223129_PERKEMBANGAN\%20DATA\%20USAHA\%20MIKRO,\%20KECI L, \%20MENENGAH\%20(UMKM)\%20DAN\%20USAHA\%20BESAR\%20(UB)\%20TAHUN\%202017\%20-\%202018.pdf

Knight, G. (2000). Entrepreneurship and marketing strategy: The SME under globalization. Journal of International Marketing, 8(2), 12-32. https://doi.org/https://www.jstor.org/stable/25048805

Knight, G. A., \& Cavusgil, S. T. (2004). Innovation, organizational capabilities, and the born-global firm. Journal of International Business Studies, 35, 124-141. https://doi.org/https://doi.org/10.1057/palgrave.jibs.8400071

Kuivalainen, O., Lindqvist, J., Ruokonen, M., \& Saarenketo, S. (2018). The Role of support services during the internationalisation of Finnish software SMEs. In Key Success Factors of SME Internationalisation: A Cross-Country Perspective (pp. 99-120). Published online: 08 Aug 2018, https://doi.org/10.1108/S1876-066X20180000034006.

Lee, W. P., Toh, T. C., Lew, Y. L., Khor, S., Goh, K. C., Gui, H. C., Zainordin, N., \& Lee, C. K. (2020). Capacity building needs of small and medium contracting enterprises in Klang Valley Malaysia. International Journal of Industrial Management, 6(1), 1727. https://doi.org/https://doi.org/10.15282/ijim.6.0.2020.5640

Leonidou, L. C., Katsikea, C. S., Palihawadana, D., \& Spyropoulou, S. (2007). An analytical review of the factors stimulating smaller firms to export: Implications for policy-makers. International Marketing Review, 24(6), 735-770. https://doi.org/https://doi.org/10.1108/02651330710832685

Manolopoulos, D., Chatzopoulou, E., \& Kattaridi, C. (2018). Resources, home institutional context and SMEs' exporting: Direct relationships and contingency effects. International Business Review, 27(5), 993-1006. https://doi.org/https://doi.org/10.1016/j.ibusrev.2018.02.011

Michael, M. S., Saban, G., Zainoren, A., \& Abdurahman, A. (2016). Factors affecting non-exporting small and medium enterprises' intention to export: Resource Based Approach. 6th International Research Symposium in Service Management, IRSSM-6, Sarawak, Kuching, Malaysia.

Morais, F., \& Franco, M. (2018). The role of cooperative alliances in internationalization strategy: Qualitative study of Portuguese SMEs in the textile sector. Journal of Strategy and Management, 11(4), 461-482. https://doi.org/https://doi.org/10.1108/JSMA03-2018-0023

Omri, W., \& Becuwe, A. (2014). Managerial characteristics and entrepreneurial internationalization: A study of Tunisian SMEs. Journal of International Entrepreneurship, 12(1), 8-42. https://doi.org/10.1007/s10843-013-0119-8

Onkelinx, J., Manolova, T. S., \& Edelman, L. F. (2015). Human capital and SME internationalization: Empirical evidence from Belgium. International Small Business Journal, 34(6), 818-837. https://doi.org/https://doi.org/10.1177/0266242615591856

Podsakoff, P. M., MacKenzie, S. B., Lee, J. Y., \& Podsakoff, N. P. (2003). Common method biases in behavioral research: a critical review of the literature and recommended remedies Journal of Applied Psychology, 88(5), 879-903. https://doi.org/10.1037/0021-9010.88.5.879

Reid, S. D. (1981). The decision-maker and export entry and expansion. Journal of International Business Studies, 12(2), 101-112. https://doi.org/https://doi.org/10.1057/palgrave.jibs.8490581

Reid, S. D. (1983). Managerial and Firm Influences on Export Behavior. Journal of the Academy of Marketing Science, 11(3), 323332. https://doi.org/https://doi.org/10.1007/BF02725228

Ribau, C. P., Moreira, A. C., \& Raposo, M. (2017). SMEs innovation capabilities and export performance: An Entrepreneurial Orientation View. Journal of Business Economics and Management, 18(5), $920-934$. https://doi.org/https://doi.org/10.3846/16111699.2017.1352534 
Safari, A., \& Saleh, A. S. (2020). Key determinants of SMEs' export performance: a resource-based view and contingency theory approach using potential mediators. Journal of Business \& Industrial Marketing, 35(4), 635-654. https://doi.org/https://doi.org/10.1108/JBIM-11-2018-0324

Saha, R. K., Singh, S. K. G., Taha, A. Z., \& Seng, T. L. (2021). The effect of toolkits usage on firms' co-creation and innovation: An empirical study on Malaysian manufacturing firms. International Journal of Industrial Management(1), 15-24. https://doi.org/ https://doi.org/10.15282/ijim.9.0.2021.5950

Sarwono, H. A. (2015). Profil Bisnis Usaha Mikro, Kecil, dan Menengah (UMKM). B. I. d. LPPI.

Serra, F., Pointon, J., \& Abdou, H. (2012). Factors influencing the propensity to export: A study of UK and Portuguese textile firms. International Business Review, 21(2), 210-224.

Styles, C., \& Ambler, T. (1994). Successful export practice: The UK experience. International Marketing Review, 11(6), $23-47$. https://doi.org/https://doi.org/10.1108/02651339410072999

Teece, D., Pisano, G., \& Shuen, A. (1997). Dynamic capabilities and strategic management. Strategic Management Journal, 18(7), 509-533. https://doi.org/https://doi.org/10.1002/(SICI)1097-0266(199708)18:7<509::AID-SMJ882>3.0.CO;2-Z

Wade, M., \& Hulland, J. (2004). Review: The resource-based view and information systems research: Review, extension, and suggestions for future research. MIS Quarterly, 28(1), 107-142. https://doi.org/10.2307/25148626

Wang, M. W. C., Tan, C. L., \& Wahid, N. A. (2020). Supplier management practice and service quality: Critical review on mediating role of outsourcing service provider capabilities. International Journal of Industrial Management, 7(1), 9-15. https://doi.org/ https://doi.org/10.15282/ijim.7.0.2020.5750

Warnerfelt, B. (1984). A resource-based view of the firm. Strategic Management Journal, 5, 171-180. https://doi.org/https://www.jstor.org/stable/2486175

Welch, L. S., \& Luostarinen, R. (1988). Internationalization: Evolution of a Concept. Journal of General Management, 14(2), $34-55$. https://doi.org/https://doi.org/10.1177/030630708801400203

Wiodomann, A. U., Schuz, B., Sniohotta, F., Scholz, U., \& Schwarzor, R. (2009). Disentangling the relation between intentions, planning, and behaviour: A moderated mediation analysis. Psychology \& Health, 24(1), 67-79. https://doi.org/10.1080/08870440801958214

\section{AUTHORS' BIOGRAPHY}

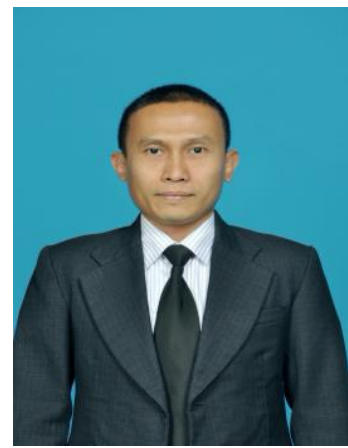

Dr. Yogi Yusuf Wibisono, ST, MT. is a a senior lecturer at the Department of Industrial Engineering, Parahyangan Catholic University, Indonesia. He completed the Doctor of Industrial Engineering at Bandung Institute of Technology, Indonesia (2018). Currently he holds Head of Master of Industrial Engineering of Parahyangan Catholic University. His research interest focuses on SMEs, internationalization, service management. Email: yogi@ unpar.ac.id.

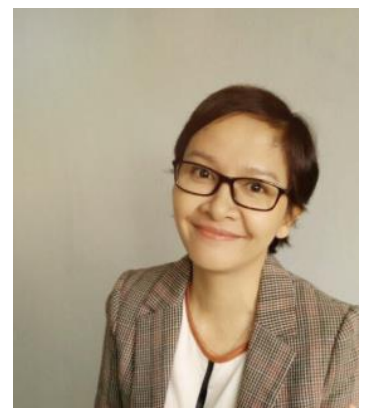

Dr. Hotna Marina Sitorus is a senior lecturer at the Department of Industrial Engineering, Parahyangan Catholic University, Indonesia. She holds a doctorate degree in Industrial Engineering and Management from Bandung Institute of Technology, Indonesia. Currently she serves as Head of Industrial Engineering Department, Parahyangan Catholic University. Her current research interests are technology and innovation adoption, SMEs, service quality, and industrial management. Her email is nina@unpar.ac.id. 